\title{
Beyond Fuel Treatment Effectiveness: Characterizing Interactions between Fire and Treatments in the US
}

\author{
Kevin Barnett ${ }^{1, *}$, Sean A. Parks ${ }^{2}$, Carol Miller ${ }^{2}$ and Helen T. Naughton ${ }^{1}$ \\ 1 Department of Economics, The University of Montana, Missoula, MT 59701, USA; \\ helen.naughton@mso.umt.edu \\ 2 Aldo Leopold Wilderness Research Institute, Rocky Mountain Research Station, USDA Forest Service, \\ Missoula, MT 59801, USA; sean_parks@fs.fed.us (S.A.P.); cmiller04@fs.fed.us (C.M.) \\ * Correspondence: kevin.barnett@umontana.edu; Tel.: +1-406-830-0130 \\ Academic Editors: Michael C. Stambaugh and Timothy A. Martin \\ Received: 13 August 2016; Accepted: 4 October 2016; Published: 14 October 2016
}

\begin{abstract}
In the United States, fuel reduction treatments are a standard land management tool to restore the structure and composition of forests that have been degraded by past management. Although treatments can have multiple purposes, their principal objective is to create landscape conditions where wildland fire can be safely managed to help achieve long-term land management goals. One critique is that fuel treatment benefits are unlikely to transpire due to the low probability that treated areas will be burned by a subsequent fire within a treatment's lifespan, but little quantitative information exists to corroborate this argument. We summarized the frequency, extent, and geographic variation of fire and fuel treatment interactions on federal lands within the conterminous United States (CONUS). We also assessed how the encounters between fuel treatments and fires varied with treatment size, treatment age, and number of times treated. Overall, $6.8 \%$ of treatment units evaluated were encountered by a subsequent fire during the study period, though this rate varied among ecoregions across the CONUS. Larger treatment units were more likely to be encountered by a fire, and treatment units were most frequently burned within one year of the most recent treatment, the latter of which is likely because of ongoing maintenance of existing treatments. Our results highlight the need to identify and prioritize additional opportunities to reduce fuel loading and fire risk on the millions of hectares of federal lands in the CONUS that are in need of restoration.
\end{abstract}

Keywords: encounter rate; treatment maintenance; treatment longevity; MTBS; LANDFIRE; wildland fire

\section{Introduction}

Interactions between historical fire exclusion, land use changes, and a warming climate have increased fuel loading and fire hazard across millions of hectares of federal forested lands in the United States [1]. Fuel reduction treatments, whereby surface and canopy fuels are removed through mechanical thinning and/or prescribed fire, are a standard management tool to reduce fire risk and restore the vegetative structure of ecosystems that have been degraded by past management and fire suppression [2,3]. Fuel treatments can moderate subsequent fire behavior [4,5], mitigate fire severity [6,7], and increase forest resilience to subsequent disturbances [8,9]. At the stand level, fuel treatment effects vary according to treatment type, size, and age [10], while their spatial arrangement and rate of implementation can affect outcomes at the landscape level [11,12]. One principal critique of fuel treatments is that their benefits are rarely realized because of the low likelihood that an unplanned fire will encounter a previously treated area during its effective lifespan [13-15], though the rate and extent to which this occurs remains largely unknown. 
Myriad economic and operational constraints to fuel treatment implementation on federal lands in the United States make it unlikely that treatments alone can achieve forest restoration goals at landscape scales [16]. Recognizing this limitation, several calls have been made to expand the use of unplanned fire to accelerate the pace of forest restoration $[17,18]$. Managing fire in fire-adapted ecosystems is challenging given the current social and institutional constraints to managing fire for resource benefits $[19,20]$. However, low-risk opportunities to use unplanned fire to achieve land management goals can be expanded when tied into existing fuel treatment networks or previously burned areas [21]. Treated areas can serve as "anchor points" [2] during incident management to facilitate indirect suppression strategies that allow fires to burn inside large areas buffered by treatments, previously burned areas, or other terrain features that limit fire spread [22] or facilitate suppression efforts [23]. Indeed, leveraging treated areas to support the use of fire is a principal objective of fuel treatment strategies [21], yet little information exists to evaluate its successes or failures.

Recognizing that the successful use of wildland fire is a necessary component of long-term fire risk management, the National Cohesive Wildland Fire Management Strategy identified priority areas where fuel treatments might be used as a precursor to a safer and expanded use of wildland fire [24]. Successfully implementing this aspect of the Cohesive Strategy requires a programmatic and strategic alignment of resources and management objectives from the national to local level; national resources are allocated across agencies and geographical regions where the need to reduce fuel loadings is most critical, and local managers respond by capitalizing on low-risk opportunities to manage unplanned ignitions to achieve long-term fire and land management objectives. Disconnects within this management framework will result in inefficiencies and help to reinforce the current fire and land management paradigm [25]. For example, suppressing wildland fire within a matrix of previously treated areas, especially during moderate weather conditions, forgoes a low-risk opportunity to capture the fuel treatment benefits provided and maintained by wildland fire [22,26]. In turn, managers will be forced to use their limited resources to retreat previously treated areas to maintain low fire hazard rather than expand treatment networks. Quantifying interactions between fuel treatments and subsequent fire at large spatial extents provides managers and policy makers with a means to track their successes and may also reveal where progress towards achieving the goals of the Cohesive Strategy is lacking.

Due to data limitations, previous attempts to characterize fire and fuel treatment interactions in the United States made broad assumptions when estimating the probability that treated areas would burn by unplanned fire [14], most notably the assumption that fire and fuel treatments are randomly located. Findings based on such assumptions may have limited ability to inform contemporary fire and fuels management strategies because the likelihood of fire occurrence and spread is known to exhibit spatial patterning and be highly variable across large landscapes $[27,28]$. The advent of modern datasets containing spatially referenced fire and fuel treatment data $[29,30]$ enables a more refined assessment of fire and fuel treatment interactions that accounts for fire's natural variability and improves our ability to assess fuel treatment efficacy.

In this study, we used spatially-explicit, standardized datasets of fuel treatments and wildland fires that occurred between 1999 and 2013 on federal lands to summarize the frequency, extent, and geographic variation of recent fire and fuel treatment interactions across the conterminous United States (CONUS). We focused on fire and fuel treatment interactions outside of the wildland-urban interface (WUI), where forest restoration goals are assumed to supersede other potential fuel treatment objectives (i.e., fire-mitigation) [31]. We quantified the percentage of fuel treatments that were encountered by subsequent fire during the study period in terms of ecoregion, treatment size, treatment regime (i.e., number of times treated), and treatment age. Our findings are discussed in the broader context of potential implications for fire and fuel management strategies. 


\section{Materials and Methods}

\subsection{Study Area}

We evaluated fire and fuel treatment interactions on federal lands in the CONUS. Federal lands were identified from the Protected Areas Database (Version 1.3, United States Geological Survey Gap Analysis Program, USA) [32] (Figure 1). We restricted our analysis to fuel treatments located $>2.5 \mathrm{~km}$ outside the WUI $[3,31]$ (Figure 2). This distance threshold has been suggested as an appropriate buffer around WUI communities for community wildfire protection zones where fire-mitigation treatments are prioritized $[33,34]$. The WUI was defined as both the 'interface', where housing is in the vicinity of contiguous vegetation, and the 'intermix', where housing and vegetation intermingle. A spatial data layer of both the interface and intermix was obtained from the SILVIS lab [35] and was developed following federal definitions of the WUI [36]. For clarity, we refer to the WUI and its $2.5 \mathrm{~km}$ buffer as $\mathrm{WUI}_{2.5}$.

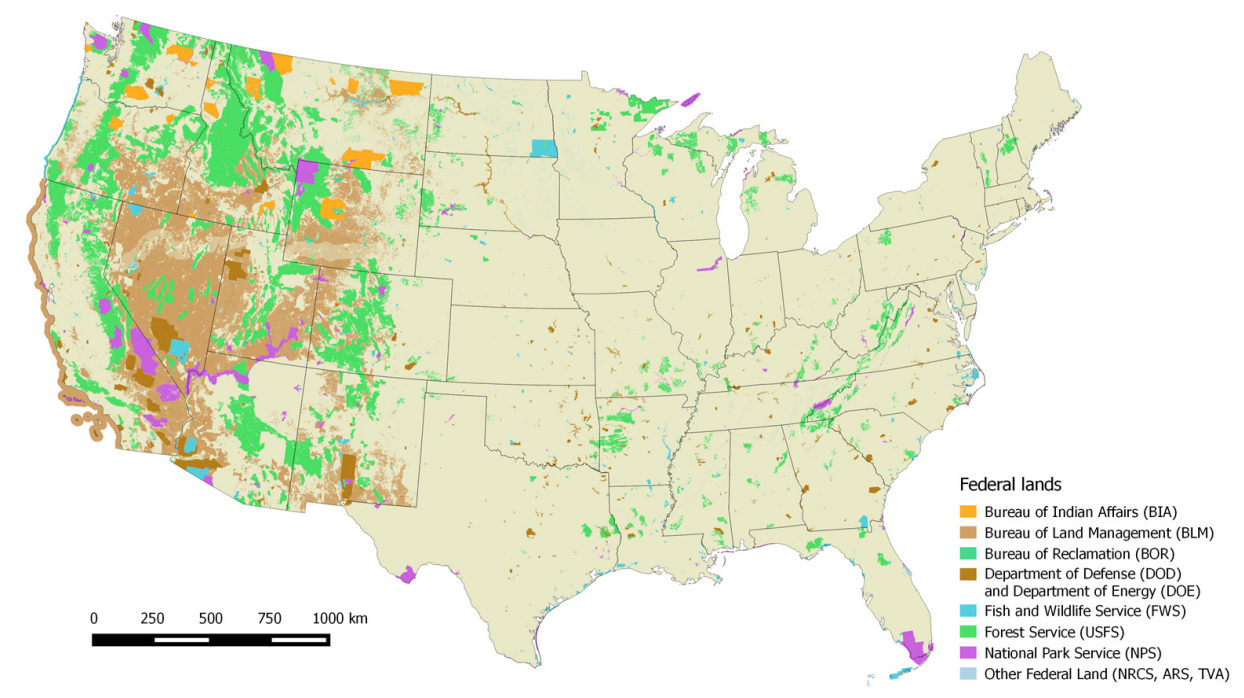

Figure 1. Map of federal lands across the conterminous United States (CONUS).

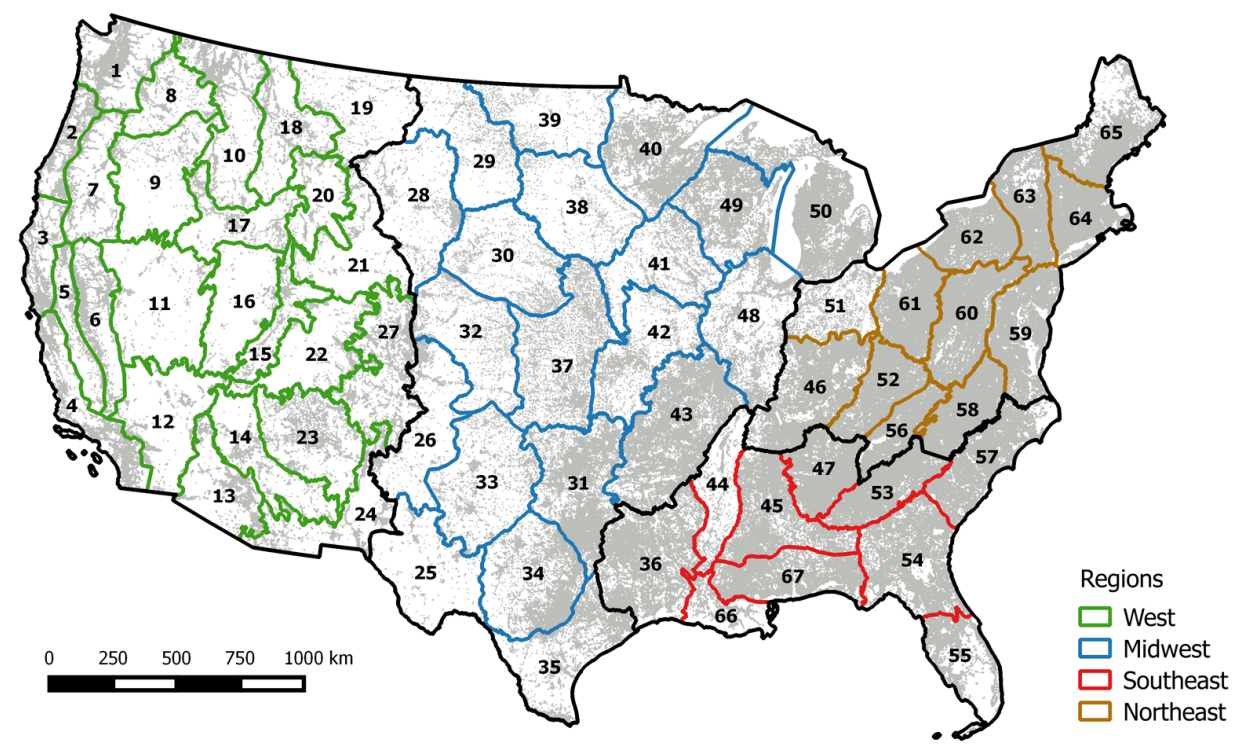

Figure 2. Distribution of wildland-urban interface (WUI) lands including $2.5 \mathrm{~km}$ buffer (gray) among regions and ecoregions of the CONUS. See Figure S1 for corresponding ecoregion names. 


\subsection{Data Background}

Our primary datasets were obtained from the LANDFIRE program [29] and the Monitoring Trends in Burn Severity (MTBS) project [30]. The LANDFIRE program produces geospatial datasets (e.g., historical fire regime, existing vegetation type, and recent fuel treatments) to support strategic fire and resource management and planning. The LANDFIRE fuel treatment dataset comprises treatment events that occurred between 1999 and 2012. Each fuel treatment event is a spatial polygon representing a treatment boundary and is attributed by year and type of treatment (Table 1).

Table 1. Description of treatment types from the LANDFIRE Public Events Data Dictionary.

\begin{tabular}{cl}
\hline Treatment Type & \multicolumn{1}{c}{ Description } \\
\hline Clearcut & $\begin{array}{l}\text { The cutting of essentially all trees, producing a fully exposed microclimate for } \\
\text { the development of a new age class }\end{array}$ \\
\hline Harvest & $\begin{array}{l}\text { A general term for the cutting, felling, and gathering of forest timber. The term } \\
\text { harvest was assigned to events where there was not enough information } \\
\text { available to call them one of the two distinct types, clearcut or thinning }\end{array}$ \\
\hline Mastication & $\begin{array}{l}\text { Means by which vegetation is mechanically "mowed" or "chipped“ into small } \\
\text { pieces and changed from a vertical to a horizontal arrangement }\end{array}$ \\
\hline Other mechanical & $\begin{array}{l}\text { Catch all term for a variety of forest and rangeland mechanical activities related } \\
\text { to fuels reduction and site preparation including: piling of fuels, chaining, lop } \\
\text { and scatter, thinning of fuels, Dixies harrow, etc. }\end{array}$ \\
\hline Prescribed fire & $\begin{array}{l}\text { Any fire ignited by management actions to meet specific objectives. A written, } \\
\text { approved prescribed fire plan must exist, and NEPA requirements (where } \\
\text { applicable) must be met prior to ignition. }\end{array}$ \\
\hline Thinning & $\begin{array}{l}\text { A tree removal practice that reduces tree density and competition between trees } \\
\text { in a stand. Thinning concentrates growth on fewer, high-quality trees, provides } \\
\text { periodic income, and generally enhances tree vigor }\end{array}$ \\
\hline
\end{tabular}

MTBS data are derived from Landsat TM, ETM+, and OLI imagery and include perimeters for fires greater than 200 ha in the eastern US and greater than 405 ha in the western US since 1984. Although these perimeter data are not without error [37], the consistent mapping methodologies and comprehensive coverage reduce potential data bias over time and space relative to other potential data sources; these data have been successfully used to investigate fire frequency, severity, and size over significant geographic and temporal extents [38-40].

Fires labeled by MTBS as 'prescribed' or 'unknown origin' were removed. Prescribed fires from the MTBS dataset that occurred between 1999 and $2012(n=4543)$ were added to the LANDFIRE fuel treatment dataset. Duplicate prescribed fire records between the LANDFIRE and MTBS datasets were subsequently removed.

\subsection{Assessing Fuel Treatment Regimes}

Many treated areas received several treatments throughout the study period, presumably for treatment maintenance purposes. For example, an area might first be mechanically thinned to reduce vertical and horizontal fuel connectivity, and then treated with prescribed fire the next year to remove residual surface fuels. In such cases of multiple treatments, we identified and delineated all sets of overlapping fuel treatment polygons that constituted a treatment 'unit' and used the most recent treatment type when summarizing interactions between treatments and subsequent fires. In the case where the two most recent treatment types comprised a mechanical treatment (i.e., clearcut, thinning, harvest, mastication, or other mechanical) followed by prescribed fire, we assigned a new treatment type, 'thin-and-burn'. To quantify treatment maintenance and summarize the overall treatment regime for a treatment unit, we recorded the number of original treatment polygons that intersected each treatment unit. Inconsistent digitizing of original treatment boundaries resulted in the creation of many 
'sliver' treatment units, so all treatment units less than $415 \mathrm{~m}^{2}$ were removed (the 1st percentile in the treatment size distribution). A total of 136,107 treatment unit polygons were identified and analyzed.

\subsection{Deriving Encounter Rates}

All treatment units that occurred on federal land from 1999 to 2012 that were encountered by a subsequent wildland fire between 2000 and 2013 were identified; by definition, treatment units could not be encountered by a fire that occurred in the same year or previous to the treatment. We calculated the encounter rate as the percentage of treatment unit polygons that were intersected by wildland fires and summarized this rate across four variables: ecoregion, treatment size class, treatment regime (i.e., number of times treated), and time-since-treatment. Sixty seven ecoregions were determined from a spatial layer obtained from The Nature Conservancy [41] which is loosely based on Bailey's ecoregion delineation [42].

Calculating encounter rates in terms of treatment age was a two-step process. First, for treatment units encountered by a subsequent fire, we calculated the time-since-treatment as the difference between the years of the fire and treatment. Where multiple treatments occurred within a treatment unit, we used the most recent treatment year before the fire occurred, and when a treatment was encountered by multiple subsequent fires, we used the earliest fire date. Second, we normalized the number of treatments within each time-since-treatment interval to remove the bias introduced by a truncated fire record. For example, only treatment units installed in 1999 were evaluated for the 14 years-since-treatment interval because treatment units installed after 1999 did not have the opportunity to be burned by a fire 14 years later. Conversely, all treatments were evaluated for the one year-since-treatment interval because treatments from each year had the opportunity to be encountered by a fire the next year. We derived encounter rate within each time-since-treatment interval as the number of treatments encountered by a subsequent fire divided by the total number of treatments within each time interval.

\section{Results}

Our final sample of 3908 unique fire events that occurred between 2000 and 2013 on federal lands in the CONUS burned a total of 18,851,801 ha. Total treated area between 1999 and 2012 was $2,804,850$ ha. A total of 9249 of the 136,483 treatment units were encountered by subsequent fire, resulting in an overall encounter rate of $6.8 \%$ (Table S1). Of the total treated area, 216,287 ha $(7.7 \%)$ burned by subsequent fire.

The number of treatments and area treated varied widely among the treatment types (Table 2). Prescribed fire was the most commonly observed fuel treatment fuel treatment type and comprised more area than all other treatment types combined. Thin-and-burn units were more frequent and comprised a larger area compared to clearcut, harvest, or mastication units.

Table 2. Summary statistics for all fuel treatment units. All areal units are in ha.

\begin{tabular}{cccc}
\hline Treatment Unit Type & $\begin{array}{c}\text { Number of } \\
\text { Treatment Units }\end{array}$ & $\begin{array}{c}\text { Total Treatment } \\
\text { Unit Area }\end{array}$ & $\begin{array}{c}\text { Mean Treatment Unit Size } \\
\text { (25th, 75th Percentiles) }\end{array}$ \\
\hline Clearcut & 2847 & 29,729 & $10.44(1.94,12.47)$ \\
Harvest & 7929 & 92,432 & $11.66(1.50,13.59)$ \\
Mastication & 2209 & 38,465 & $17.41(0.49,14.73)$ \\
Other mechanical & 29,173 & 473,957 & $16.25(0.40,9.50)$ \\
Prescribed fire & 47,261 & $1,631,087$ & $34.51(0.29,11.20)$ \\
Thin-and-burn & 9397 & 107,311 & $11.42(0.72,12.36)$ \\
Thinning & 37,667 & 431,869 & $11.47(1.74,13.13)$ \\
\hline
\end{tabular}

Treated area and area burned varied among ecoregions (Figure 3). Treated area was greatest in the Cascade Mountain Range (303,731 ha), Blue Mountain Region of the Columbia Plateau (252,501 ha), 
and Floridian Coastal Plain (229,163 ha) (Figure 3a). The highest area burned by wildland fires on federal lands occurred in the western United States (Blue Mountain Region of the Columbia Plateau, Snake River Plain, and Northwestern Rocky Mountains ecoregions) (Figure 3b). In the eastern CONUS, area burned was greatest in the Southeastern Coastal Plain ecoregion. Five ecoregions contained zero wildland fires on federal lands during the study period.

Treated area burned tended to exhibit similar spatial patterns to treated area, although some ecoregions of the interior western United States with relatively high treated area had relatively low treated area burned (e.g., Wyoming Basin, Middle Rocky Mountains) (Figure 3c). The encounter rate substantially varied among ecoregions (Figure 3d). The highest encounter rates across the CONUS were observed in the Southern California, Mogollon Rim, and Snake River Plains ecoregions. Encounter rate was less than $5 \%$ in 19 of the 25 westernmost ecoregions. During the study period, there were 23 ecoregions with a $0 \%$ encounter rate.
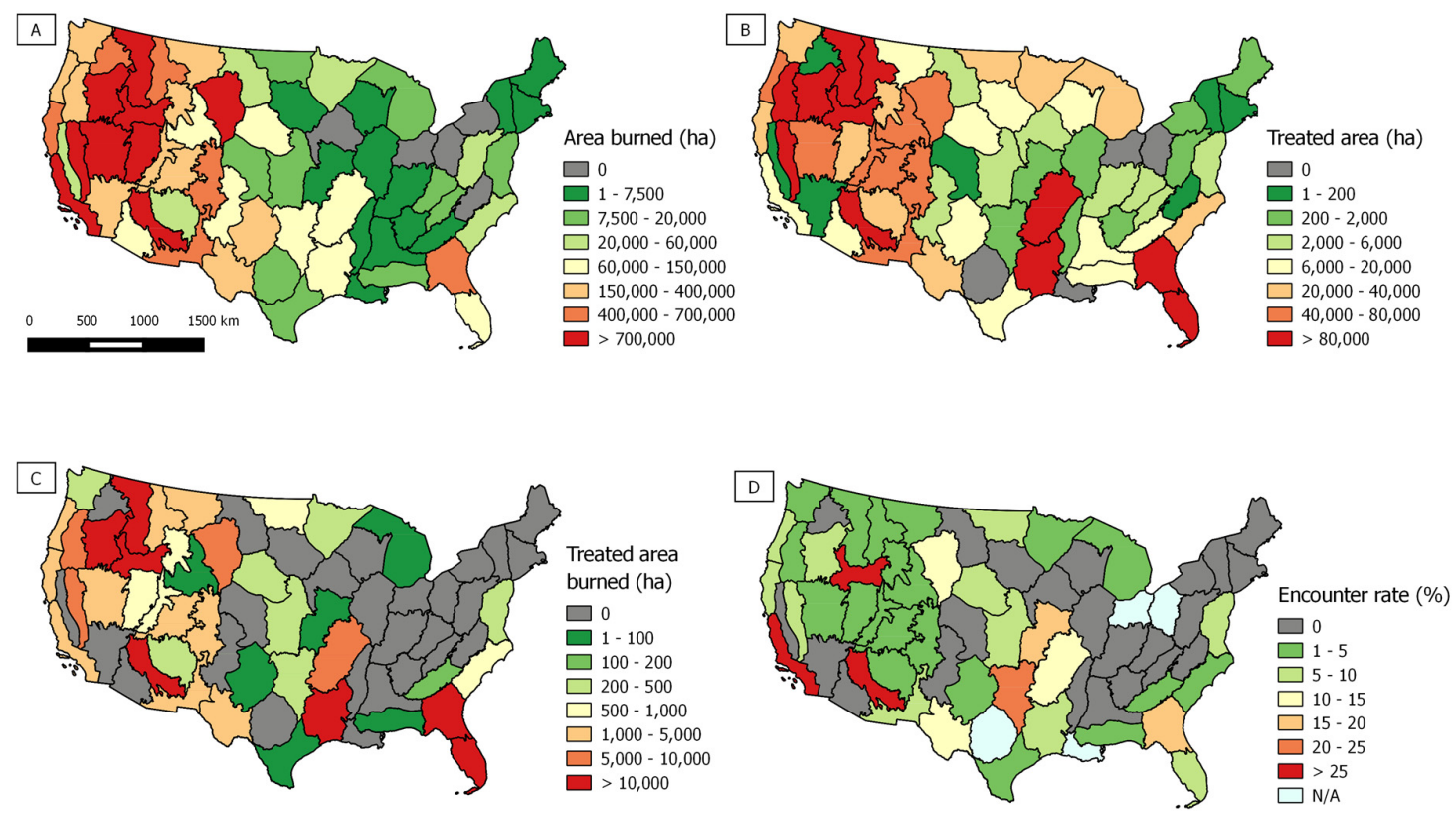

Figure 3. Distribution of (A) area burned; (B) treated area; (C) treated area burned; and (D) the encounter rate between fuel treatments and fires on federal lands, summarized for each of 67 ecoregions across the CONUS.

The encounter rate increased with treatment size, especially when treatments were larger than 200 ha (Table 3). However, only $1.4 \%$ of all treatment units evaluated were greater than 200 ha. About one-third of all fuel treatment units received at least two treatments during the study period (Table 4). The vast majority of treated area $(77.6 \%)$ and treated area that was subsequently burned by fire $(70.5 \%)$, however, was attributable to treatment units that only received one treatment during the study period. Encounter rates between treatments and subsequent fires increased with number of times treated (Table 4).

Encounter rates were highest within one year of the most recent treatment and tended to decline with time since treatment (Figure 4). 
Table 3. Summary statistics of frequency, area treated, treated area burned by wildland fire, and encounter rate by treatment unit size class.

\begin{tabular}{ccccc}
\hline $\begin{array}{c}\text { Treatment Unit } \\
\text { Size Class (ha) }\end{array}$ & $\begin{array}{c}\text { Number of } \\
\text { Treatments }\end{array}$ & $\begin{array}{c}\text { Area Treated } \\
\text { (ha) }\end{array}$ & $\begin{array}{c}\text { Treated Area } \\
\text { Burned (ha) }\end{array}$ & $\begin{array}{c}\text { Encounter Rate } \\
\text { (\%) }\end{array}$ \\
\hline $0-5$ & 74,966 & 99,547 & 6331 & 6.8 \\
$5-10$ & 21,809 & 158,899 & 9718 & 6.5 \\
$10-25$ & 24,156 & 374,289 & 21,107 & 6.2 \\
$25-50$ & 8125 & 281,081 & 15,543 & 6.8 \\
$50-100$ & 3755 & 259,466 & 13,981 & 7.2 \\
$100-200$ & 1753 & 244,308 & 11,783 & 8.1 \\
$200-500$ & 1122 & 352,008 & 23,844 & 10.9 \\
$500-1000$ & 503 & 352,731 & 23,907 & 15.5 \\
$1000-5000$ & 276 & 498,034 & 61,382 & 21.4 \\
$>5000$ & 18 & 184,486 & 28,690 & 50.0 \\
\hline
\end{tabular}

Table 4. Summary statistics of frequency, area treated, treated area burned by wildland fire, and encounter rate by treatment regime.

\begin{tabular}{ccccc}
\hline $\begin{array}{c}\text { Number of } \\
\text { Times Treated }\end{array}$ & $\begin{array}{c}\text { Number of } \\
\text { Treatments }\end{array}$ & $\begin{array}{c}\text { Area Treated } \\
\text { (ha) }\end{array}$ & $\begin{array}{c}\text { Treated Area } \\
\text { Burned (ha) }\end{array}$ & $\begin{array}{c}\text { Encounter Rate } \\
\text { (\%) }\end{array}$ \\
\hline 1 & 85,337 & $2,178,223$ & 152,405 & 5.2 \\
2 & 32,955 & 461,365 & 42,889 & 7.9 \\
3 & 12,143 & 126,897 & 17,985 & 11.3 \\
4 & 3992 & 25,021 & 2206 & 13.3 \\
$\geq 5$ & 2056 & 13,344 & 802 & 15.7 \\
\hline
\end{tabular}

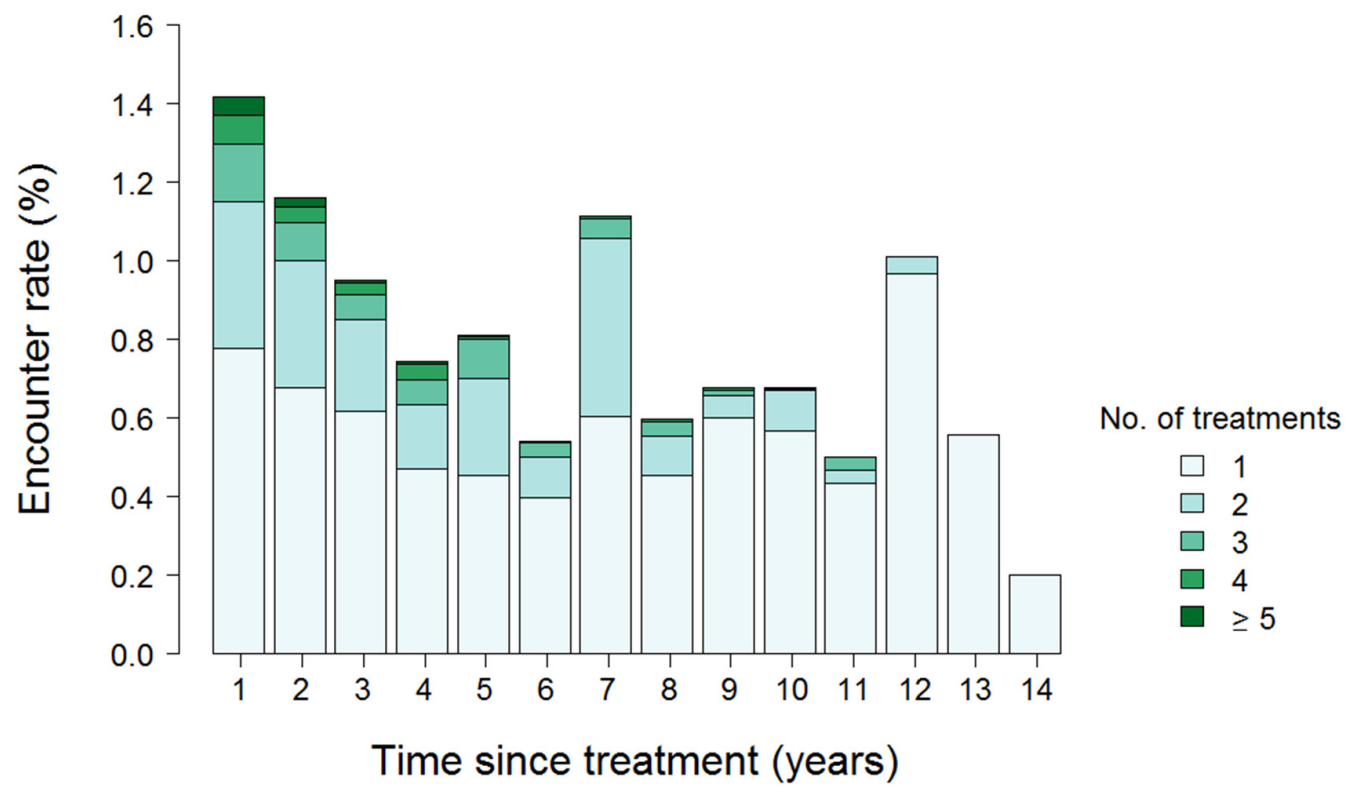

Figure 4. Encounter rate as a function of time since most recent treatment and treatment regime. Number of treatments represents the number of times an area was treated before being encountered by a subsequent fire.

\section{Discussion}

Characterizing interactions among fuel treatments and wildland fires at broad spatial and temporal scales is an important step to track investments made in fuels reduction programs. Prior efforts have quantified interactions between certain types of fuel treatments and subsequent fire. Rhodes and Baker [14] estimated that between $7.2 \%$ and $16.5 \%$ of treated areas in ponderosa pine 
forests of the western United States are encountered by fire within 20 years of treatment assuming random locations of fire and fuel treatments. An empirical study in southeastern Australia found that $22.5 \%$ of all prescribed fire patches were subsequently burned by unplanned fire within five years [43]. Our more comprehensive CONUS-wide analysis examined additional fuel treatment types and we observed similar, though somewhat lower encounter rates overall. We found that $6.8 \%$ of treatment units created between 1999 and 2012 on federal lands outside of the $\mathrm{WUI}_{2.5}$ were encountered by a subsequent fire by 2013.

The Cohesive Strategy identified portions of both the western and southeastern United States as priority areas for active restoration where wildland fire can be more safely used to help achieve long-term land management objectives [24]. In the southeastern United States, treated area was relatively high in four ecoregions (Ouachita Hills, Ozark Highlands, Southeastern Coastal Plain, and Floridian Coastal Plain), and their associated encounter rates were slightly higher than those found in much of the western US (Figure 3). Although western ecoregions contained the highest area burned and treated area during the study period, only six ecoregions experienced encounter rates greater than $5 \%$. Treated area was relatively high across the western CONUS but did not correlate to encounter rates (Spearman's $r=0.12$ ); several western ecoregions had high treated area but a low encounter rate (e.g., Northwestern Rocky Mountains, Cascade Mountain Range, and Blue Mountain Region of the Columbia Plateau). This finding has implications for fuels treatment planning in the western US because simply treating more area may not help to achieve long-term fire and land management goals if wildland fire cannot be safely managed. Strategically placing fuel treatments to create conditions where wildland fire can occur without negative consequences [21] and leveraging low-risk opportunities to manage wildland fire will remain critical factors to successful implementation of the Cohesive Strategy.

Not surprisingly, we found that the encounter rate increased with treatment unit size (Table 4). In addition to being more likely to be encountered, larger fuel treatments can be more effective at moderating fire behavior relative to smaller treatments because they contain more interior area and less edge $[7,44,45]$. Implementing large fuel reduction treatments in fire-excluded forests on federal lands, however, is challenging due to regulatory and funding constraints [46]. Indeed, our fuel treatment data suggest that $55 \%$ of all fuel treatment units on federal lands were less than 5 ha, while only $2.7 \%$ of treatment units were greater than 100 ha. These large fuel treatment units (i.e., $>100$ ha) comprised a significant amount of the total treated area burned; 149,606 ha out of the 216,287 ha $(69.2 \%)$ of treated area burned occurred within large treatment units. A large portion of this (59,324 ha) occurred inside large treatment units in three ecoregions in southeastern United States where large tracts of federal lands are regularly treated with prescribed fire (i.e., Ouachita Hills, Floridian Coastal Plains, Southeastern Coastal Plain) (Figure S1) [47]. For comparison, 72,447 ha of treated area burned within large treatment units in the ten most treated ecoregions of the western CONUS combined, with over half $(37,420$ ha) attributable to the Snake River Plain ecoregion alone. Because many of the regulatory, institutional, and social barriers to large scale fuel treatment implementation are likely to remain in place in the near future, alternative solutions to reducing fuel loads across millions of hectares of federal lands, especially in dry forests of the western CONUS, are needed [16].

Fuel treatment longevity is influenced by several factors, including treatment type, vegetation, and fuel decomposition and accumulation rates [10]. Treatment longevity can be extended by applying prescribed or managed fire within the temporal window that fuel treatments remain effective to consume surface fuels and regenerating vegetation that increase fire hazard [48]. In general, treatments have been found to be most effective at moderating fire behavior within the first few years of treatment [49], though in less productive forest types with low fuel accumulation rates, treatments can moderate burn severity for up to 20 years post-treatment [7]. In this study, encounters of fuel treatment units with a subsequent fire occurred most frequently within one year of the most recent treatment (Figure 4). However, nearly half of the treatment units encountered by a fire within one year of treatment had received at least two treatments during our study period. This finding reveals the tradeoff that exists between management of existing treatments to maintain low fire hazard and 
implementation of additional treatments to reduce fire risk at larger spatial extents [48]. Treatment maintenance is a necessary component of fuel management [2], but maintenance comes at the expense of restoring additional forested lands. One option to extend the longevity of existing treatments is to leverage treated areas during incident management to encourage the use of unplanned fire to maintain and create low fire hazard conditions $[17,48]$. Wildland fire can rapidly change landscape structure and successional pathways at much larger spatial extents than restoration treatments [18]. Indeed, our data show that the ratio of area burned by wildland fire to treated area exceeds 5:1 for most of the western CONUS ecoregions (Figure S2). The long-term success of fuels management programs depends upon the successful use of fire to achieve land management goals [21], but with only $7.8 \%$ of the total treated area in the CONUS burned by a subsequent fire, our results suggest that existing treatments are not being sufficiently exploited to accelerate the pace of forest restoration.

Even though we used the best spatial datasets available to quantify encounters between treatments and subsequent fires, these estimates cannot be used to formally evaluate the success of fuels management at the programmatic level without additional context. Comparing these encounter rates with what might occur under random chance may highlight where in the CONUS they are lower or higher than their expected value. Such an analysis could address whether or not treatments are being strategically placed across large landscapes. Geospatial decision support tools can prioritize treatment locations to establish large, contiguous tracts of land where managed fire can occur without loss of important ecological functions, such as those provided by old growth stands of a fire-resistant species [50]. Implementing such treatment regimens could potentially increase encounter rates and help expedite restoration of forest ecosystems. In addition, risk-based decision support tools are being developed to identify low-risk opportunities for the management of unplanned ignitions [51,52]. Integrating these two approaches could aid local fuel treatment planning efforts by identifying priority areas for active restoration where managed fire can occur without posing an excessive risk to resources, assets, and ecological values.

Although we used the most comprehensive, standardized datasets of fire and fuel treatments available, our analysis was limited by the length and completeness of the data records. While we observed relatively low encounter rates, it's expected they will increase as time goes on, especially if projections of increasing fire activity in North America are accurate [53,54]. Continued efforts to maintain and distribute spatial databases of fire and fuel treatments will aid future investigations of fuel treatment and fire interactions. We focused on treatments and encounter rates occurring outside of the $\mathrm{WUI}_{2.5}$ because treatments in these areas are more likely to have had the goal of forest restoration [31]. However, we recognize that these treatments may have included other fire and land management objectives, including WUI protection [31], and may have helped to achieve important land management goals unrelated to forest restoration and independent of being encountered by a wildland fire. Future research can evaluate fire and fuel treatment interactions with respect to treatment objectives when such data become available. MTBS fire perimeters can fail to detect unburned islands and oversimplify complex polygon geometries [55]; these limitations are unlikely to affect the interpretation of our results due to the spatial scale of our analysis and the metrics we summarize. Even though large, recently treated areas can mitigate fire spread [56] and therefore affect future encounter rates, we did not explicitly evaluate fire sizes. This is likely to have a negligible effect on our results because $98.6 \%$ of treatments in our dataset were less than 200 ha and the average fire size was 4824 ha. Lastly, the LANDFIRE fuel treatment dataset is by no means a complete record of all treatments implemented on federal lands, and its accuracy is likely to vary among the agencies and groups who contributed their data. Nonetheless, we found it useful in this broad scale analysis as a first approximation of fuel treatment and fire interactions across the CONUS.

\section{Conclusions}

In this study, we used standardized spatial datasets of fire and fuel treatments to systematically quantify the frequency, extent, and geographic variation of fire and fuel treatment interactions on 
federal lands across the CONUS. Overall, we found that $6.8 \%$ of treatment units between 1999 and 2012 were encountered by a subsequent fire through 2013, with significant geographic variability among ecoregions. Identifying opportunities to jointly reduce fuel loadings on federal lands and safely reintroduce wildland fire will likely remain a priority into the near future. Continued maintenance and distribution of standardized spatial datasets of fire and fuel treatments will allow researchers to monitor interactions among fuel treatments and fires over space and time, hopefully exposing opportunities to improve both fire and fuel treatment planning and management to expedite forest restoration on federal lands.

Supplementary Materials: The following are available online at http:/ / www.mdpi.com/1999-4907/7/10/237/s1, Table S1: Summary statistics of wildland fires, fuel treatments, and their interactions across ecoregions of the CONUS, Figure S1: Distribution of WUI lands including $2.5 \mathrm{~km}$ buffer (gray) among regions and ecoregions of the CONUS, Figure S2: Map showing the ratio of area burned to area treated across ecoregions of the CONUS.

Acknowledgments: We thank two anonymous reviewers for thoughtful comments that significantly improved the manuscript. Funding for this research was provided by the Joint Fire Science Program under Project 14-5-01-25.

Author Contributions: K.B., S.A.P., C.M., and H.T.N. conceived and designed the experiments; K.B. performed the experiments; K.B. analyzed the data; K.B., S.A.P., C.M., and H.T.N. wrote the paper.

Conflicts of Interest: The authors declare no conflict of interest. The founding sponsors had no role in the design of the study; in the collection, analyses, or interpretation of data; in the writing of the manuscript, and in the decision to publish the results.

\section{References}

1. Stephens, S.L.; Ruth, L.W. Federal forest-fire policy in the United States. Ecol. Appl. 2005, 15, 532-542. [CrossRef]

2. Agee, J.K.; Skinner, C.N. Basic principles of forest fuel reduction treatments. For. Ecol. Manag. 2005, 211, 83-96. [CrossRef]

3. Schoennagel, T.; Nelson, C.R. Restoration relevance of recent National Fire Plan treatments in forests of the western United States. Front. Ecol. Environ. 2011, 9, 271-277. [CrossRef]

4. Finney, M.A. Design of regular landscape fuel treatment patterns for modifying fire growth and behavior. For. Sci. 2001, 47, 219-228.

5. Stephens, S.L.; Moghaddas, J.J. Experimental fuel treatment impacts on forest structure, potential fire behavior, and predicted tree mortality in a California mixed conifer forest. For. Ecol. Manag. 2005, 215, 21-36. [CrossRef]

6. Safford, H.D.; Schmidt, D.A.; Carlson, C.H. Effects of fuel treatments on fire severity in an area of wildland-urban interface, Angora Fire, Lake Tahoe Basin, California. For. Ecol. Manag. 2009, 5, $773-787$. [CrossRef]

7. Pritchard, S.J.; Kennedy, M.C. Fuel treatment and landform modify landscape patterns of burn severity in an extreme fire event. Ecol. Appl. 2014, 24, 571-590. [CrossRef]

8. Stevens, J.T.; Safford, H.D.; Latimer, A.M. Wildfire-contingent effects of fuel treatments can promote ecological resilience in seasonally dry conifer forests. Can. J. For. Res. 2014, 44, 843-854. [CrossRef]

9. Hood, S.M.; Baker, S.; Sala, A. Fortifying the forest: Thinning and burning increase resistance to bark beetle outbreak and promote forest resiliency. Ecol. Appl. 2016, in press. [CrossRef]

10. Kalies, E.L.; Yocom Kent, L.L. Tamm Review: Are fuel treatments effective at achieving ecological and social objectives? A systematic review. For. Ecol. Manag. 2016, 375, 84-95. [CrossRef]

11. Finney, M.A.; Seli, R.C.; McHugh, C.W.; Ager, A.A.; Bahro, B.; Agee, J.K. Simulation of long-term landscape-level fuel treatment effects on large fires. Int. J. Wildland Fire 2008, 16, 712-717. [CrossRef]

12. Ager, A.A.; Vaillant, N.M.; Finney, M.A. A comparison of landscape fuel treatment strategies to mitigate wildland fire risk in the urban interface and preserve old growth structure. For. Ecol. Manag. 2010, 259, 1556-1570. [CrossRef]

13. Rhodes, J.J.; Odion, D.C. Evaluation of the efficacy of forest manipulations still needed. BioScience 2004, 54, 980. [CrossRef]

14. Rhodes, J.J.; Baker, W.L. Fire probability, fuel treatment effectiveness and ecological tradeoffs in western U.S. public forests. Open For. Sci. J. 2008, 1, 1-7. 
15. Campbell, J.L.; Harmon, M.E.; Mitchell, S.R. Can fuel-reduction treatments really increase forest carbon storage in the western US by reducing future fire emissions? Front. Ecol. Environ. 2011, 10, 83-90. [CrossRef]

16. North, M.; Brough, A.; Long, J.; Collins, B.; Bowden, P.; Yasuda, D.; Miller, J.; Sugihara, N. Constraints on mechanized treatment significantly limit mechanical fuels reduction extent in the Sierra Nevada. J. For. 2015, 113, 40-48. [CrossRef]

17. North, M.P.; Collins, B.M.; Stephens, S.L. Using fire to increase the scale, benefits and future maintenance of fuels treatments. J. For. 2012, 110, 392-401. [CrossRef]

18. Hessburg, P.F.; Churchill, D.J.; Larson, A.J.; Haugo, R.D.; Miller, C.; Spies, T.A.; North, M.P.; Povak, N.A.; Belote, R.T.; Singleton, P.H.; et al. Restoring fire-prone Inland Pacific landscapes: Seven core principles. Landsc. Ecol. 2015, 30, 1805-1835. [CrossRef]

19. Doane, D.L.; O'Laughlin, J.; Morgan, P.; Miller, C. Barriers to wildland fire use: A preliminary problem analysis. Int. J. Wilderness 2006, 12, 36-38.

20. Black, A.; Williamson, M.; Doane, D. Wildland fire use barriers and facilitators. Fire Manag. Today 2008, 68, 10-14.

21. Reinhardt, E.D.; Keane, R.E.; Calkin, D.E.; Cohen, J.D. Objectives and considerations for wildland fuel treatment in forested ecosystems of the interior western United States. For. Ecol. Manag. 2008, 256, 1997-2006. [CrossRef]

22. Parks, S.A.; Holsinger, L.M.; Miller, C.; Nelson, C.R. Wildland fire as a self-regulating mechanism: The role of previous burns and fire in limited fire progression. Ecol. Appl. 2015, 25, 1478-1492. [CrossRef] [PubMed]

23. Moghaddas, J.J; Craggs, L. A fuel treatment reduces fire severity and increases suppression efficiency in a mixed conifer forest. Int. J. Wildland Fire 2008, 16, 673-678. [CrossRef]

24. The National Strategy: The Final Phase in the Development of the National Cohesive Wildland Fire Management Strategy. Available online: https://www.forestsandrangelands.gov/strategy/documents / strategy/CSPhaseIIINationalStrategyApr2014.pdf (accessed on 27 July 2016).

25. Calkin, D.E.; Thompson, M.P.; Finney, M.A. Negative consequences of positive feedbacks in US wildfire management. For. Ecosyst. 2015, 2, 9. [CrossRef]

26. Parks, S.A.; Miller, C.; Nelson, C.R.; Holden, Z.A. Previous fires moderate burn severity of subsequent wildland fires in two large western US wilderness areas. Ecosystems 2014, 17, 29-42. [CrossRef]

27. Parks, S.A.; Parisien, M.A.; Miller, C. Multi-scale evaluation of the environmental controls on burn probability in a southern Sierra Nevada landscape. Int. J. Wildland Fire. 2011, 20, 815-828. [CrossRef]

28. Parisien, M.A.; Snetsinger, S.; Greenberg, J.A.; Nelson, C.R.; Schoennagel, T.; Dobrowski, S.Z.; Moritz, M.A. Spatial variability in wildfire probability across the western United States. Int. J. Wildland Fire 2012, 21, 313-327. [CrossRef]

29. Eidenshink, J.C.; Schwind, B.; Brewer, K.; Zhu, Z.L.; Quayle, B.; Howard, S.M. A project for monitoring trends in burn severity. Fire Ecol. 2007, 3, 3-21. [CrossRef]

30. Rollins, M.G. LANDFIRE: A nationally consistent vegetation, wildland fire, and fuel assessment. Int. J. Wildland Fire 2009, 18, 235-249. [CrossRef]

31. Schoennagel, T.; Nelson, C.R.; Theobald, D.M.; Carnwath, G.C.; Chapman, T.B. Implementation of National Fire Plan treatments near the wildland-urban interface in the western United States. Proc. Natl. Acad. Sci. USA 2009, 106, 10706-10711. [CrossRef] [PubMed]

32. Gergely, K.J.; McKerrow, A. PAD-US-National Inventory of Protected Areas: U.S. Geological Survey Fact Sheet 2013-3086. Available online: http:/ / pubs.usgs.gov/fs/2013/3086/pdf/fs20133086.pdf (accessed on 11 October 2016).

33. Theobald, D.M.; Romme, W.H. Expansion of the US wildland-urban interface. Landsc. Urban Plan. 2007, 83, 340-354. [CrossRef]

34. Aplet, G.H.; Wilmer, B. The wildland fire challenge: Protecting communities and restoring ecosystems. George Wright Forum 2005, 22, 32-44.

35. Radeloff, V.C.; Hammer, R.B.; Stewart, S.I.; Fried, J.S.; Holcomb, S.S.; McKeefry, J.F. The wildland-urban interface in the United States. Ecol. Appl. 2005, 15, 799-805. [CrossRef]

36. USDA \& USDI. Urban Wildland Interface Communities within Vicinity of Federal Lands That Are at High Risk from Wildlife; Federal Register: Washington, DC, USA, 2001; Volume 66, pp. 751-777.

37. Kolden, C.A.; Lutz, J.A.; Key, C.H.; Kane, J.T.; van Wagtendonk, J.W. Mapped versus actual burned area within wildfire perimeters: Characterizing the unburned. For. Ecol. Manag. 2012, 286, 38-47. [CrossRef] 
38. Miller, J.D.; Safford, H. Trends in wildfire severity: 1984-2010 in the Sierra Nevada, Modoc Plateau, and Southern Cascades, California, USA. Fire Ecol. 2012, 8, 41-57. [CrossRef]

39. Riley, K.L.; Abatzoglou, J.T.; Grenfell, I.C.; Klene, A.E.; Heinsch, F.A. The relationship of large fire occurrence with drought and fire danger indices in the western USA, 1984-2008: The role of temporal scale. Int. J. Wildland Fire. 2013, 22, 894-909. [CrossRef]

40. Parks, S.A.; Parisien, M.A.; Miller, C.; Dobrowski, S.Z. Fire activity and severity in the western US vary along proxy gradients representing fuel amount and fuel moisture. PLoS ONE 2014, 9, e99699. [CrossRef] [PubMed]

41. The Nature Conservancy. Terrestrial Ecoregions. Available online: map.tnc.org/gis_data.html (accessed on 11 October 2016).

42. Bailey, R.G. Descriptions of the Ecoregions of the United States, 2nd ed.; USDA Forest Service: Washington, DC, USA, 1995.

43. Price, O.F.; Bradstock, R.A. The effect of fuel age on the spread of fire in sclerophyll forest in the Sydney region of Australia. Int. J. Wildland Fire. 2010, 19, 35-45. [CrossRef]

44. Safford, H.D.; Stevens, J.T.; Merriam, K.; Meyer, M.D.; Latimer, A.M. Fuel treatment effectiveness in California yellow pine and mixed conifer forests. For. Ecol. Manag. 2012, 274, 17-28. [CrossRef]

45. Kennedy, M.C.; Johnson, M.C. Fuel treatment prescriptions alter spatial patterns of fire severity around the wildland-urban interface during the Wallow Fire, Arizona, USA. For. Ecol. Manag. 2014, 318, 122-132. [CrossRef]

46. Collins, B.M.; Stephens, S.L.; Moghaddas, J.J.; Battles, J. Challenges and approaches in planning fuel treatments across fire-excluded forested landscapes. J. For. 2010, 108, 24-31.

47. Stephens, S.L. Forest fire causes and extent on United States Forest Service lands. Int. J. Wildland Fire 2005, 14, 213-222. [CrossRef]

48. Stephens, S.L.; Collins, B.M.; Roller, G. Fuel treatment longevity in a Sierra Nevada mixed conifer forest. For. Ecol. Manag. 2012, 285, 204-212. [CrossRef]

49. Martinson, E.J.; Omi, P.N. Fuel Treatments and Fire Severity: A Meta-Analysis; USDA Forest Service: Fort Collins, CO, USA, 2013.

50. Ager, A.A.; Vaillant, N.M.; McMahan, A. Restoration of fire in managed forests: A model to prioritize landscapes and analyze tradeoffs. Ecosphere 2013, 4, 1-19. [CrossRef]

51. Thompson, M.P.; Bowden, P.; Brough, A.; Scott, J.H.; Gilbertson-Day, J.; Taylor, A.; Anderson, J.; Haas, J.R. Application of wildfire risk assessment results to wildfire response planning in the southern Sierra Nevada, California, USA. Forests 2016, 7, 64. [CrossRef]

52. Barnett, K.; Miller, C.; Venn, T.J. Using risk analysis to reveal opportunities for the management of unplanned ignitions in wilderness. J. For. 2016, in press.

53. Krawchuk, M.A.; Moritz, M.A.; Parisien, M.A.; Van Dorn, J.; Hayhoe, K. Global pyrogeography: The current and future distribution of wildfire. PLoS ONE 2009, 4, e5102. [CrossRef] [PubMed]

54. Littell, J.S.; Oneil, E.E.; McKenzie, D.; Hicke, J.A.; Lutz, J.A.; Norheim, R.A.; Elsner, M.M. Forest ecosystems, disturbance, and climatic change in Washington State, USA. Clim. Chang. 2010, 102, 129-158. [CrossRef]

55. Sparks, A.M.; Boschetti, L.; Smith, A.M.S.; Tinkham, W.T.; Lannom, K.O.; Newingham, B.A. An accuracy assessment of the MTBS burned area product for shrub-steppe fires in the northern Great Basin, United States. Int. J. Wildland Fire 2015, 24, 70-78. [CrossRef]

56. Finney, M.A.; McHugh, C.W.; Grenfell, I.C. Stand- and landscape-level effects of prescribed burning on two Arizona wildfires. Can. J. For. Res. 2005, 35, 1714-1722. [CrossRef]

(C) 2016 by the authors; licensee MDPI, Basel, Switzerland. This article is an open access article distributed under the terms and conditions of the Creative Commons Attribution (CC-BY) license (http:/ / creativecommons.org/licenses/by/4.0/). 